\title{
Peningkatan Kemampuan Menulis Puisi Melalui Teknik Clustering dengan Media Foto Jurnalistik Pada Siswa Kelas VIII.6 di SMP Negeri 13 Pekanbaru
}

\author{
Rismaneti * \\ * SMP Negeri 13 Pekanbaru
}

\begin{tabular}{l}
\hline INFO ARTIKEL \\
\hline Riwayat Artikel: \\
Diterima: 6 Maret 2018 \\
Disetujui: 10 Juni 2018
\end{tabular}

Kata kunci:
Kemampuan Menulis Puisi
Teknik Clustering
Media Foto Jurnalistik

Alamat Korespondensi:

Rismaneti,

SMP Negeri 13 Pekanbaru

Jl. Ronggowarsito I No. 15 Pekanbaru

E-mail: rismaneti@gmail.com

\begin{abstract}
ABSTRAK
Abstract: Based on preliminary observations made, it was found that the ability to write poetry of class VIII students of SMP Negeri 13 Pekanbaru was still lacking. The lack of students' ability to write poetry is caused by three factors, namely factors from the teacher, students, and the environment. The factor of the teacher is the lack of use of techniques and media that vary in learning to write. Factors of students, namely students find it difficult to express ideas that are in their minds, difficulty finding the right words to be arranged into poetry, and the difficulty to imagine. The factors of the environment are the lack of facilities and infrastructure owned by the school. Based on the explanation above, this study examines two problems, namely (1) how is the improvement in poetry writing ability of eighth grade students of SMP Negeri 13 Pekanbaru after learning through clustering techniques with photojournalism media, and (2) how is the behavior of class VIII students of SMP Negeri 13 Pekanbaru in learning poetry writing uses clustering techniques with journalistic photo media. This study uses a classroom action research design conducted in two stages, namely cycle I, and cycle II with research subjects of class VIII Pekanbaru State Junior High School 13. Data collection is done by using test and non-test techniques. Non-data was obtained from observations, interviews, student diaries, teacher journals, and photo documentation. Data analysis includes quantitative and qualitative data. From the results of the first cycle, and the second cycle that students have experienced an increase in each aspect of writing poetry, this is evident from the acquisition of each aspect of writing poetry such as the suitability of the title with the content in the first cycle. increased by $6 \%$ to 82.7 . For aspects of the choice of words or diction, the increase in the first cycle obtained an average value of 76.0 and the second cycle became 80.5 with an increase of $4.5 \%$. Figurative language aspects of the average value of students in the first cycle 63.2, then in the second cycle increased by $17.3 \%$ with an average value of 80.5 . For the versification aspect the acquisition of the average value in the first cycle was 60.2 and in the second cycle it was 80.5 with an increase of $20.3 \%$. The latter for typographic aspects of the acquisition of the average value of the first cycle of 72.7 and in the second cycle became 76.7 so as to obtain an increase of $04 \%$.
\end{abstract}

\section{LATAR BELAKANG}

Menulis adalah kemampuan menggunakan bahasa untuk berkomunikasi dengan menggunakan bahasa tulis. Seorang penulis berkomunikasi melalui tulisan mereka untuk mempengaruhi pembacanya. Komunikasi tersebut berlangsung melalui bahasa tulis. Komunikasi antara penulis dengan pembaca berlangsung saat 
114 Instructional Development Journal (IDJ), Vol. 1, No. 1, Juni 2018, Hal. 113-121

tulisan tersebut dibaca oleh orang lain. Kemampuan menulis sangat dibutuhkan di dalam kehidupan yang serba modern ini. Komunikasi akan lebih banyak berlangsung secara tertulis. Sehubungan dengan hal tersebut, ada seorang penulis yang mengatakan bahwa menulis dipergunakan oleh orang terpelajar untuk mencatat, merekam, meyakinkan, melaporkan, memberitahukan, dan mempengaruhi. Oleh karena itu,kemampuan menulis sangat penting dan harus dikuasai dengan baik. Salah satu langkah pemerintah untuk menumbuhkan budaya menulis dengan cara mencantumkan menulis dalam salah satu keterampilan berbahasa yang harus dikuasai oleh siswa. Pembelajaran menulis terbagi menjadi dua yaitu menulis bahasa dan menulis sastra. Aspek menulis bahasa meliputi menulis berita, menulis teks pengumuman, menulis surat dinas, dan sebagainya. Sedangkan aspek menulis sastra terdiri atas menulis puisi, menulis prosa, dan menulis drama.

Salah satu pembelajaran menulis sastra atau menulis kreatif sastra adalah menulis puisi. Menulis puisi merupakan sebuah kegiatan menulis kreatif karena dibutuhkan kreatifitas penulis untuk mengungkapkan perasaan mereka dalam puisi melalui tulisan. Perasaan yang diungkapkan penulis dalam puisi menggunakan bahasa yang figuratif dan terdapat pemadatan kata sehingga menimbulkan kesan ekspresif dan tidak meninggalkan kesan estetis. Pembelajaran menulis puisi memiliki arti yang penting sehingga dilaksanakan hampir pada semua jenjang pendidikan mulai dari SD-SMA. Siswa yang sering menulis puisi akan menjadi terampil dan terarah kemampuan berekspresinya sehingga secara tidak langsung akan mempertajam kemampuan berpikir. Kemampuan menulis puisi tidak bisa diperoleh hanya dengan latihan sekali namun kemampuan tersebut harus dilatih secara terus-menerus. Sering berlatih akan meningkatkan kemampuan menulis siswa.Kemampuan menulis puisi diajarkan kepada siswa agar bisa bersikap lebih kritis untuk menghadapi suatu situasi. Siswa bisa memanfaatkan kemampuan menulisnya untuk menghasilkan suatu karya yang ekspresif dan menarik untuk dibaca orang lain. Suatu karya yang ekspresif dan menarik akan menimbulkan kepuasan tersendiri bagi penulisnya.

Kenyataan yang ada di sekolah menunjukkan bahwa banyak siswa yang masih kesulitan menulis sebuah puisi. Hal tersebut dapat dilihat dari hasil wawancara peneliti dengan guru bahasa Indonesia di SMP Negeri 13 Pekanbaru dan wawancara dengan beberapa siswa. Sebagian siswa merasa kesulitan untuk menulis puisi khususnya saat siswa harus menentukan kata yang akan mereka tulis menjadi puisi. Pembelajaran menulis puisi biasanya dilakukan dengan meminta siswa keluar kelas, setelah itu mereka harus menuliskan puisi yang berkaitan dengan apa yang mereka lihat saat di luar kelas. Cara tersebut cukup efektif, namun terkadang ada siswa yang merasa kesulitan menentukan objek apa yang akan mereka tulis. Siswa harus diarahkan untuk menentukan sebuah objek yang akan mereka jadikan sumber menulis puisi.

Guru berpendapat bahwa penggunaan metode ceramah lebih efektif daripada menggunakan metode konstruktivisme. Metode ceramah terkadang memang lebih efektif namun tidak semua materi bisa diajarkan hanya dengan menyampaikan teorinya saja. Untuk pembelajaran menulis puisi sebaiknya seorang guru mengajak siswa untuk praktik secara langsung agar mereka lebih mahir. Kemampuan menulis puisi tidak bisa didapat jika siswa hanya diberi teoriteori tentang menulis puisi saja. Penyebab berikutnya berasal dari diri anak itu sendiri. Munculnya anggapan pada sebagian siswa bahwa pelajaran bahasa Indonesia merupakan mata pelajaran yang mudah karena merupakan bahasa sendiri yang sering digunakan dalam kehidupan mereka. Faktor tersebut yang menjadikan siswa malas dan kurang berminat untuk mengikuti pembelajaran. Selain itu, siswa mengalami kesulitan saat diminta untuk mengungkapkan ide atau gagasan ke dalam sebuah tulisan. Hal tersebut dikarenakan mereka tidak terbiasa untuk mencurahkan gagasan dalam bentuk bahasa tulis.

Fakta lain yang diperoleh peneliti saat observasi yaitu siswa kurang menyukai aspek menulis sastra karena mereka merasa kesulitan untuk menikmati karya sastra yang disampaikan oleh guru. Terkadang guru menyampaikan pelajaran tentang karya sastra dengan cara yang monoton tanpa memanfaatkan media yang menarik bagi siswa. Hal tersebut yang menjadi alasan seorang siswa kurang menyukai pembelajaran menulis puisi. Faktor ketiga berasal dari lingkungan (sekolah dan luar sekolah). Pengadaan sarana dan prasarana yang lengkap untuk siswa menjadi faktor pendukung yang seharusnya bisa menjadikan siswa lebih mudah mengembangkan kemampuan mereka. Sarana dan prasarana tersebut lebih khusus tentang media pendukung proses belajar mengajar. Faktor lain berasal dari lingkungan luar sekolah yaitu munculnya 
beberapa anggapan dan pendapat bahwa pembelajaran sastra dianggap kurang penting karena jumlah soal dalam ujian untuk aspek sastra hanya beberapa dan ternyata jauh lebih sedikit jika dibandingkan dengan aspek bahasa.

Berdasarkan uraian diatas, dapat disimpulkan bahwa permasalahan yang dialami oleh siswa saat pembelajaran menulis puisi sangat beragam. Masalah utama yang harus segera diatasi adalah kesulitan siswa untuk menemukan kata-kata yang tepat untuk dibuat sebuah puisi. Masalah berikutnya adalah kesulitan siswa untuk berimajinasi tentang hal apa yang akan mereka jadikan bahan menulis puisi. Salah satu alternatif untuk membantu siswa mengatasi kesulitan yang dihadapi adalah melalui teknik clustering dan media foto jurnalistik. Alasan penggunaan teknik clustering karena teknik tersebut dapat membantu siswa untuk menemukan kata yang cocok untuk dijadikan sebuah puisi. Teknik ini digunakan untuk mengelompokan kata-kata yang nantinya harus dikembangkan oleh siswa menjadi sebuah puisi. Kata-kata yang harus dikelompokkan oleh siswa bisa mereka temukan setelah melihat foto jurnalistik. Alasan penggunaan media foto jurnalistik karena media tersebut dapat membantu siswa saat mereka merasa kesulitan harus berimajinasi tentang isi puisi yang akan mereka tulis. Penggunaan media foto jurnalistik juga dapat meningkatkan antusiasme siswa dalam pembelajaran menulis puisi karena media ini lebih menarik jika dibandingkan dengan media lainnya. Media foto yang akan digunakan merupakan foto yang ada di media massa dan menunjukkan satu kejadian yang menarik untuk dibuat puisi.

Rico (dalam DePorter 2002:180) menyebutkan bahwa pengelompokan ini dilakukan untuk memilahmilah gagasan yang ada dalam pikiran tiap manusia. Gagasan tersebut dipilah dengan dituangkan di atas kertas secepat mungkin tanpa pertimbangan dan penyuntingan. Teknik clustering ini merupakan modifikasi dari teknik mind mapping (peta pikiran). Peta pikiran (mind mapping) adalah metode mencatat kreatif yang memudahkan mengingat informasi (DePorter, dkk 2008:175). Jadi, teknik mind mapping pada awalnya digunakan untuk memudahkan mencatat dan mengingat informasi. Hernowo (2009) menjelaskan bahwa teknik clustering merupakan teknik menulis dengan cara mengelompokan ide secara cepat dengan bantuan gambar. Cara mengoperasikan teknik ini berlandaskan temuan Roger Sperry yang menunjukkan bahwa ada dua belahan otak di kepala yang masing-masing belahan tersebut berfungsi secara berbeda. Kedua belahan itu disebut belahan otak kiri (left hemisphere)-yang suka ketertiban serta bersimbolkan teks dan belahan otak kanan (right hemisphere)-yang suka kebebasan serta bersimbolkan gambar. Langkah pokok teknik clustering seperti layaknya bermain puzzle karena dimulai dengan melihat dan menyusun kepingan-kepingan kecil. Langkah dalam teknik ini dimulai dari seseorang diminta untuk menuliskan kepingan-kepingan puzzle (kelompok kecil) ide terlebih dahulu, kemudian setelah kepingan itu terkumpul banyak periksa kembali kata yang sudah ditulis, kemudian coret kata atau gagasan yang tidak ingin ditelusuri lebih mendalam, langkah terakhir kepingankepingan tersebut mulai dikaitkan satu sama lain. Berdasarkan uraian beberapa ahli, dapat disimpulkan bahwa teknik clustering merupakan salah satu teknik yang digunakan saat menulis dengan cara mengelompokkan kata-kata kemudian kata tersebut dirangkai untuk menemukan sebuah ide tulisan yang utuh. Langkah dalam teknik clustering dimulai dengan menuliskan kata-kata, kemudian coret kata atau gagasan yang tidak ingin ditelusuri lebih mendalam, dan langkah terakhir kata-kata atau gagasan tersebut dikaitkan sehingga terbentuklah sebuah ide yang utuh sebagai bahan tulisan.

Sebuah teknik tidak akan berhasil apabila tidak disesuaikan dengan keadaan dan materi yang akan diajarkan. Untuk itu, peneliti memilih teknik clustering dan media foto jurnalistik untuk diterapkan dalam pembelajaran menulis puisi karena menurut peneliti penggunaan teknik dan media tersebut cocok apabila digunakan dalam pembelajaran materi tersebut. Penggunaan teknik clustering dan media foto jurnalistik diharapkan mampu mengatasi kesulitan siswa saat harus memilih kata dan kesulitan siswa saat harus berimajinasi sebelum mereka menulis sebuah puisi. Penggunaan foto jurnalistik dimaksudkan untuk membantu saat siswa harus membayangkan sebuah peristiwa sebelum mereka menciptakan sebuah puisi. Kemudian pemilihan teknik clustering agar siswa lebih mudah memilah-milah dan mengelompokkan katakata yang akan digunakan untuk menciptakan sebuah puisi. Kelompok-kelompok kata tersebut akan 
116 Instructional Development Journal (IDJ), Vol. 1, No. 1, Juni 2018, Hal. 113-121

membantu siswa agar mereka lebih terarah kata apa saja yang cocok dan sesuai dengan foto yang mereka miliki.

Penerapan teknik clustering dan media foto jurnalistik dalam pembelajaran menulis puisi dilakukan dengan beberapa langkah. Langkah pertama siswa diberi sebuah foto jurnalistik dan diminta untuk mengamati foto tersebut. Kemudian siswa diberi kertas kosong. Setelah itu siswa diminta untuk menuliskan satu kata atau lebih hal yang paling menarik dari foto jurnalistik di bagian tengah kertas sebagai poros utama. Selanjutnya siswa diminta untuk menuliskan secepat mungkin daftar kata atau asosiasi dari kata yang menjadi poros utama di sekitar kata tersebut. Setelah itu siswa melihat kembali daftar kata yang sudah ditulis sudah sesuai dengan foto jurnalistik atau belum, apabila tidak sesuai coret kata tersebut. Setelah terkumpul menjadi satu gagasan utuh, kembangkan kata-kata tersebut menjadi sebuah puisi. Berikutnya untuk mengetahui hasil tulisan siswa maka tiap siswa diminta untuk membacakan hasil karya mereka di depan kelas dan siswa lain memberikan penilaian terhadap hasil karya temannya.

Berdasarkan latar belakang tersebut maka akan dilakukan penelitian dengan judul Peningkatan Kemampuan Menulis Puisi Siswa Kelas VIII.6 SMP Negeri 13 Pekanbaru Melalui Teknik Clustering dengan Media Foto Jurnalistik.

\section{METODE}

Penelitian yang akan dilakukan adalah penelitian tindakan kelas, dengan menggunakan dua siklus. Tiap siklus terdiri atas tahap perencanaan, tindakan, observasi, dan refleksi. Pada tahap perencanaan, peneliti menyusun rancangan mengajar, termasuk mempersiapkan rencana pelaksanaan pembelajaran (RPP). Selanjutnya peneliti melakukan kegiatan pembelajaran dengan melaksanakan tindakan yang dilakukan pada penelitian. Setelah dilakukan tindakan, peneliti melakukan observasi terhadap kegiatan pembelajaran yang telah dilakukan. Tahap terakhir peneliti melakukan refleksi kegiatan-kegiatan yang telah dilakukan. Kelebihan yang ada pada siklus I akan dipertahankan, sedangkan kekurangan dalam siklus I akan diperbaiki pada siklus II.

Subjek penelitian ini adalah siswa kelas VIII SMP Negeri 13 Pekanbaru tahun ajaran 2017/2018. Kelas yang dipilih adalah kelas VIII.6 yang terdiri atas 40 siswa. Kelas tersebut dipilih karena guru bahasa dan sastra Indonesia di SMP Negeri 13 Pekanbaru diketahui bahwa kemampuan menulis puisi siswa kelas tersebut masih kurang. Kesulitan siswa untuk menentukan kata-kata yang sesuaidan saat mereka harus berimajinasi untuk menulis sebuah puisi menjadi penyebab rendahnya kemampuan menulis puisi mereka. Instrumen dalam penelitian ini terdiri atas instrumen tes dan instrumen nontes. Instrumen tes diperoleh dari hasil tes menulis puisi siswa kelas VIII.6 SMP Negeri 13 Pekanbaru. Kemudian untuk instrumen nontes diperoleh dari data hasil observasi, wawancara, catatan harian siswa, jurnal guru, dan dokumentasi foto. Teknik analisis data pada penelitian ini dilakukan secara kualitatif dan kuantitatif.

Teknik kualitatif ini diperoleh dari data nontes, yaitu: observasi, wawancara, catatan harian siswa, jurnal guru, dan dokumentasi foto. Data observasi dan jurnal guru kemudian dikelompokkan berdasarkan aspekaspekyang diteliti. Data observasi, dan catatan harian siswa digunakan untuk memilih siswa yang mengalami kesulitan untuk dijadikan responden dalam wawancara. Data wawancara digunakan untuk mengetahui kesulitan belajar yang dialami siswa sehingga dapat dicari penyelesaiannya untuk meningkatkan kemampuan menulis puisi. Adapun dokumentasi dalam penelitian ini berfungsi untuk memperoleh data nontes yang berupa gambar foto yang diambil peneliti dan dibantu teman sejawat pada proses pembelajaran siklus I dan siklus II sedang berlangsung sebagai bukti otentik proses pembelajaran yang telah dilakukan. Teknik kuantitatif dilakukan untuk menganalisis data yang diperoleh siswa setelah tes dilakukan. Tes dalam penelitian ini dilakukan sebanyak dua kali, yaitu pada akhir siklus I dan akhir siklus II. Nilai masing-masing siswa pada setiap akhir sikklus dijumlahkan, kemudian jumlah tersebut dihitung persentase dengan menggunakan rumus:

$$
N P=\frac{N k}{R} x 100 \%
$$


Keterangan:

$\mathrm{NP} \quad=$ Nilai dalam presentase

$\mathrm{NK} \quad=$ Nilai kumulatif

$\mathrm{R} \quad=$ Jumlah responden

Hasil yang diperoleh dari siklus I dan siklus II dibandingkan dengan cara melihat hasil tes dan nontes, sehingga akan dapat diketahui adanya peningkatan keterampilan menulis puisi siswa dan perubahan perilaku siswa.

\section{HASIL DAN PEMBAHASAN}

\section{Hasil Penelitian Siklus I}

Setelah dilakukan pembelajaran pada siklus I dapat disimpulkan bahwa hasil pembelajaran menulis puisi yang dicapai siswa belum mencapai nilai ketuntasan belajar sebesar 80. Nilai rata-rata kelas yang dicapai pada siklus I sebesar 69,66. Hal tersebut disebabkan beberapa aspek penilaian nilai rata-rata siswa masih kurang. Nilai yang kurang memuaskan terdapat pada aspek bahasa figuratif, dan versifikasi. Nilai ratarata untuk kedua aspek tersebut masih kurang dari nilai ketuntasan belajar yang telah ditentukan sebelumnya karena beberapa siswa terlihat kurang bersungguh-sungguh saat mengerjakan tes tersebut dan waktu yang telah diberikan oleh guru tidak dimanfaatkan dengan baik oleh siswa. Saat guru memberikan penjelasan materi menulis puisi, beberapa siswa terlihat kurang konsentrasi dan kurang memperhatikan penjelasan yang disampaikan oleh guru.

Berdasarkan hasil observasi siswa, sebagian besar sudah bersikap positif dan aktif selama pembelajaran menulis puisi berlangsung. Namun, masih terdapat beberapa siswa yang berperilaku negatif. Perilaku negatif yang dilakukan siswa antara lain sering melihat pekerjaan teman, siswa pasif dan malas untuk bertanya tentang materi menulis puisi, dan terdapat satu siswa yang mengantuk. Perilaku negatif tersebut harus segera diatasi agar pada pertemuan berikutnya lebih baik lagi. Simpulan dari hasil catatan harian siswa dan jurnal guru maka dapat diketahui tanggapan siswa dan guru terhadap pembelajaran menulis puisi. Beberapa siswa masih mengalami kesulitan dalam melakukan pembelajaran menulis puisi melalui teknik clustering dengan media foto jurnalistik. Kesulitan yang dihadapi siswa sesuai dengan catatan harian yang sudah mereka tulis yaitu merasa kesulitan saat memilih kata, dan merangkainya menjadi sebuah puisi. Adapun dari jurnal guru menyatakan bahwa siswa sudah senang dalam pembelajaran menulis puisi dan siswa terlihat lebih aktif serta bersemangat untuk mengikuti pembelajaran menulis puisi. Tanggapan guru terhadap pembelajaran menulis puisi melalui teknik clustering dengan media foto jurnalistik yaitu dapat melatih siswa untuk berlatih mandiri. Siswa terlihat lebih senang karena teknik tersebut belum pernah dilakukan sebelumnya. Berdasarkan hasil wawancara yang diwakili oleh siswa yang mendapat nilai tinggi, sedang, dan rendah dapat disimpulan bahwa siswa tersebut merasa senang dan tertarik dalam pembelajaran menulis puisi. Untuk penjelasan guru dalam pembelajaran menulis puisi itu, siswa yang mendapat nilai rendah menjawab merasa kesulitan untuk memahami penjelasan guru karena guru menjelaskan terlalu cepat. Jadi, untuk mengatasi kesulitan itu guru (peneliti) harus menggunakan cara yang mudah dalam penyampaian materi. Hasil dokumentasi pada siklus I dapat dilihat perilaku-perilaku siswa yang positif dan negatif ketika pembelajaran sedang berlangsung. Beberapa siswa yang telah mencapai nilai baik disebabkan mereka menulis puisi dengan baik dan materi yang disampaikan guru diperhatikan dengan baik. Kemudian dari hasil dokumentasi foto dapat terlihat beberapa siswa yang berperilaku negatif yaitu berbicara dengan teman. Namun sebagian besar siswa terlihat bersemangat dan sangat antusias saat pembelajaran berlangsung.

Berdasarkan analisis terhadap beberapa kekurangan-kekurangan yang terjadi pada siklus I, peneliti menemukan beberapa kekurangan yaitu: (1) beberapa siswa terlihat kurang konsentrasi dan kurang antusias saat mengetahui akan belajar menulis puisi, (2) beberapa siswa kurang memperhatikan penjelasan guru, (3) beberapa siswa malas bertanya dan terlihat pasif saat pembelajaran menulis puisi, (4) nilai siswa pada aspek bahasa figuratif dan versifikasi masih kurnag dari target yang telah ditentukan, dan (5) siswa kurang bersemangat saat diminta untuk membacakan hasil karya mereka. Adapun solusi yang dilakukan peneliti terhadap kekurangan- 
118 Instructional Development Journal (IDJ), Vol. 1, No. 1, Juni 2018, Hal. 113-121

kekurangan yang terjadi antara lain: (1) guru memberikan contoh sastrawan yang bisa sukses karena menulis puisi, (2) sesekali guru mengajak siswa untuk bercanda agar siswa tidak bosan, (3) guru memberikan beberapa pertanyaan yang memancing siswa untuk menjawab, (4) guru memberikan contoh berupa puisi yang memiliki unsur pembangun dengan lengkap dan puisi yang tidak baik, dan (5) guru memberikan reward kepada siswa yang aktif.

Untuk mencapai pembelajaran yang sesuai dengan harapan guru maka kendala-kendala yang ada dalam pembelajaran menulis puisi harus dicarikan solusi yang terbaik kemudian diterapkan dalam pembelajaran. Hal-hal yang dilakukan guru berkenaan dengan upaya perbaikan yang kemudian diterapkan dalam pembelajaran selanjutnya adalah sebagai berikut (a) guru merefleksi hasil tes dan nontes pada siklus I, (b) guru menjelaskan kesalahan-kesalahan ketika mengerjakan tugas yang diberikan guru, (c) guru memberikan penjelasan tentang pentingnya unsur pembangun puisi saat menulis puisi, dan (d) guru memberikan motivasi pada siswa yaitu dengan memberikan reward bagi siswa yang mendapat nilai tertinggi dan siswa yang aktif dalam pembelajaran. Perbaikan-perbaikan ini diharapkan dapat meningkatkan hasil belajar siswa dalam pembelajaran menulis puisi pada siklus berikutnya.

\section{Hasil Penelitian Siklus II}

Pembelajaran pada siklus II telah dilaksanakan maka hasil pembelajaran menulis puisi yang dicapai siswa sudah mencapai nilai ketuntasan belajar sebesar 75 Nilai rata-rata pada siklus II sebesar 80 . Hasil pada siklus II sudah mengalami peningkatan dari 66 menjadi 80,2 Selain itu, sebagian besar siswa telah melakukan pembelajaran menulis puisi dengan baik. Dari hasil observasi pada siklus II maka dapat dilihat beberapa perilaku negatif yang ditunjukkan oleh siswa seperti keluar kelas, sering melihat pekerjaan teman, pasif dan malas bertanya, serta mengantuk sudah tidak terlihat lagi. Hanya ada 3 siswa yang melakukan kegiatan negatif tersebut. Adapun untuk kategori positif mengalami peningkatan dari siklus sebelumnya. Hasil catatan harian siswa sudah menunjukan perbaikan ke arah yang positif. Siswa merasa senang, tertarik, dan terbantu dengan adanya teknik clustering dan media foto jurnalistik untuk menulis puisi. Kesulitan yang dihadapi siswa juga sudah berkurang. Hanya beberapa siswa yang memeroleh nilai rendah yang masih mengalami kesulitan saat merangkai kata menjadi puisi. Simpulan dari jurnal guru dapat diketahui bahwa hanya sedikit yang mengalami kesulitan dalam melakukan pembelajaran menulis puisi melalui teknik clustering dengan media foto jurnalistik. Dari jurnal guru dapat diketahui bahwa siswa terlihat senang dan lebih bersemangat dalam pembelajaran menulis puisi.

Berdasarkan hasil wawancara yang diwakili oleh siswa yang mendapat nilai tinggi, sedang, dan rendah dapat disimpulkan bahwa siswa tersebut senang dan tertarik dalam pembelajaran menulis puisi. Untuk penjelasan guru dalam pembelajaran menulis puisi itu, siswa yang mendapat nilai rendah masih sulit memahami penjelasan guru, sama seperti siklus I. Berdasarkan hasil dokumentasi pada siklus II maka terlihat perilaku-perilaku siswa yang negatif ketika pembelajaran sedang berlangsung. Akan tetapi tidak sebanyak siklus I. Siswa yang telah mencapai nilai yang baik disebabkan mereka menulis puisi dengan penuh perhatian dan memperhatikan materi yang disampaikan guru dengan baik. Dalam pembelajaran siklus II ini guru sudah mencoba upaya-upaya perbaikan agar hasil pembelajaran pada siklus II lebih baik daripada siklus I. Akhirnya peneliti (guru) telah berhasil melaksanakan pembelajaran menulis puisi pada siklus II ini. Hal ini terbukti adanya hasil tes dan nontes siswa telah mengalami peningkatan.

Penelitian yang dilakukan merupakan penelitian tindakan kelas yang terdiri atas dua siklus yaitu siklus I dan siklus II. Setiap siklus melalui beberapa tahap, yaitu perencanaan, tindakan, pengamatan (observasi), dan refleksi. Pada siklus II, tahap-tahap tersebut dilaksanakan dengan perbaikan dari pembelajaran siklus I.

Pada siklus I, proses pembelajaran diawali dengan mengondisikan siswa agar siap untuk mengikuti pembelajaran menulis puisi dengan menanyakan keadaan siswa, mengadakan kegiatan apersepsi diawali dengan memberikan ilustrasi tentang pembelajaran menulis puisi. Pada kegiatan ini terdapat beberapa siswa yang masih mengobrol dengan siswa lain. Hal tersebut dapat dilihat dari data nontes berupa dokumentasi foto yang menunjukan masih ada siswa masih mengobrol dengan teman dibangku belakangnya. Kemudian siswa diminta untuk memperhatikan penjelasan yang disampaikan guru. Kegiatan awal berikutnya yaitu 
menanyakan pengalaman menulis puisi, dan menyampaikan tujuan dan manfaat pembelajaran menulis puisi. Hal ini dilakukan sebagai upaya menumbuhkan minat belajar siswa, siswa memiliki motivasi belajar terlebih dahulu. Pada kegiatan tersebut siswa terlihat mulai antusias memperhatikan penjelasan guru. Siswa mulai aktif untuk bertanya tentang penjelasan yang diberikan guru. Pada kegiatan pembelajaran menulis puisi siklus I terdapat beberapa siswa yang belum memperhatikan dengan serius, banyak melihat pekerjaan teman, dan mengantuk saat mendengarkan penjelasan guru. Data tersebut diperoleh dari observasi yang dilakukan selama pembelajaran berlangsung. Berdasarkan hasil tes, observasi, wawancara, catatan harian siswa, jurnal guru, dan dokumentasi fotopada siklus I, dapat mengetahui kelemahan-kelemahan yang dialami siswa selama pembelajaran berlangsung.

Proses pembelajaran siklus II hampir sama dengan proses pembelajaran siklus I, yaitu diawali dengan mengondisikan siswa agar siap untuk mengikuti pembelajaran menulis puisi dengan menanyakan kembali materi yang telah disampaikan pada pertemuan sebelumnya. Siswa menjawab setiap pertanyaan yang disampaikan oleh guru. Siswa terlihat lebih siap menerima pembelajaran jika dibandingkan dengan kegiatan pembelajaran pada siklus I. Kemudian guru mengulas kembali hasil tulisan siswa, dan guru menanyakan kesulitan yang dialami siswa saat menulis puisi melalui teknik clustering dengan media foto jurnalistik. Siswa menyampaikan semua kesulitan yang mereka rasakan saat melakukan kegiatan pembelajaran menulis puisi. Pada kegiatan awal ini, siswa terlihat lebih serius dan memperhatikan dengan saksama penjelasan yang disampaikan guru. Perubahan tingkah laku tersebut dapat terlihat dari observasi,dan dokumentasi foto.

Berikut ini uraian mengenai peningkatan kemampuan menulis puisi dari proses pembelajaran menulis puisi melalui teknik clustering dengan media foto jurnalistik pada siklus I, dan siklus II.

Peningkatan kemampuan menulis puisi tiap aspek di tiap siklus (siklus I, dan siklus II). Peningkatan tersebut dapat dilihat dari hasil tes yang menunjukan adanya peningkatan nilai rata-rata siswa pada tiap aspek. Simpulan yang dapat diambil dari hasil siklus I, dan siklus II bahwa siswa sudah mengalami peningkatan di tiap aspek menulis puisi, ini terbukti dari perolehan rata-rata tiap aspek menulis puisi seperti aspek kesesuaian judul dengan isi pada siklus I nilai rata-rata 76,7 adapun di siklus II mengalami peningkatan sebesar $6 \%$ menjadi 82,7 . Untuk aspek pilihan kata atau diksi mengalami peningkatan pada siklus I diperoleh nilai rata-rata 76,0 dan siklus II menjadi 80,5 dengan peningkatan sebesar 4,5\%. Aspek bahasa figuratif nilai rata-rata siswa pada siklus I 63,2 kemudian pada siklus II mengalami peningkatan sebesar 17,3\% dengan nilai ratarata 80,5. Untuk aspek versifikasi perolehan nilai rata-rata pada siklus I 60,2 dan pada siklus II menjadi 80,5 dengan peningkatan sebesar 20,3\%. Yang terakhir untuk aspek tipografi perolehan nilai rata-rata siklus I 72,7 dan pada siklus II menjadi 76,7 sehinggan memeroleh peningkatan sebesar $04 \%$. .

Pembahasan selanjutnya yaitu mengenai perubahan perilaku siswa dalam mengikuti proses pembelajaran menulis puisi melalui teknik clustering dengan media foto jurnalistik pada siklus I dan siklus II. Perubahan perilaku tersebut diperoleh dari observasi, wawancara, catatan harian siswa, jurnal guru, dan dokumentasi foto, yang dipaparkan dalam uraian di bawah ini. Dari hasil nontes yaitu melalui observasi pada siklus I kesiapan siswa untuk mengikuti pembelajaran melalui teknik clustering dengan media foto jurnalistik terlihat, sikap siswa dalam menerima materi pembelajaran belum terfokus. Hal ini dibuktikan dengan adanya beberapa siswa yang bercanda, adanya siswa yang sering melihat pekerjaan teman, adanya siswa yang tidak bersemangat, dan ada siswa yang mengantuk saat mengikuti pembelajaran. Pada siklus II sudah ada perubahan perilaku siswa. kesiapan mengikuti pelajaran sudah mulai terlihat sejak awal pembelajaran, dan sikap siswa dalam menerima pelajaran sudah mulai terfokus, sebagian besar siswa mencatat materi yang disampaikan oleh guru dan mereka nampak serius memperhatikan penjelasan yang diberikan guru, hanya beberapa siswa saja yang masih tetap mengobrol sendiri.

Hasil wawancara dari siklus I dan siklus II terdapat peningkatan. Hal tersebut ditunjukan dari jawaban yang disampaikan siswa yang memiliki nilai tinggi, sedang, dan rendah. Untuk pertanyaan pertama, ketiga siswa tersebut menjawab pernah menulis puisi. Namun siswa yang memiliki nilai rendah menjawab pernah menulis puisi saat diberi tugas oleh guru. Kemudian pada siklus II semua siswa menjawab sudah pernah menulis puisi. Saat ditanya apakah siswa merasa senang dan tertarik menulis puisi melalui 
120 Instructional Development Journal (IDJ), Vol. 1, No. 1, Juni 2018, Hal. 113-121

teknik tersebut semua siswa menjawab senang dan tertarik. Pertanyaan tentang jenis puisi yang sering ditulis, mereka semua menjawab puisi tentang cinta karena menurut mereka jauh lebih mudah menulis puisi tentang cinta daripada harus menulis puisi tentang tema yang lainnya. Pertanyaan berikutnya tentang kesulitan yang dialami, siswa yang memiliki nilai tinggi dan sedang menjawab tidak mengalami kesulitan saat harus menulis puisi melalui teknik clustering dengan media foto jurnalistik. Untuk siswa yang memiliki nilai rendah menjawab masih mengalami kesulitan. Hal tersebut mengalami perubahan perilaku yang sebelumnya pada siklus I hanya siswa yang memeroleh nilai tinggi yang menjawab tidak mengalami kesulitan saat menulis puisi.

Berdasarkan hasil catatan harian siswa dari siklus I dan siklus II yaitu siswa semakin senang terhadap teknik clustering dengan media foto jurnalistik. Menurut sebagian besar siswa kelas VIII.6 SMP Negeri 13 Pekanbaru yang menyatakan bahwa teknik tersebut dapat mempermudah mereka dalam menulis puisi karena kesulitan-kesulitan yang mereka hadapi dapat diatasi dengan teknik tersebut. Siswa merasa sangat menyenangkan dan dapat meningkatkan kreativitas siswa dalam menulis puisi. Selain itu teknik tersebut juga dapat memotivasi dan menumbuhkan minat bagi siswa untuk menulis puisi. Berdasarkan hasil jurnal guru dari siklus I ke siklus II diperoleh hasil bahwa siswa sudah mengalami perubahan tingkah laku ke arah yang positif. Sebagian besar siswa sudah mulai memperhatikan penjelasan yang diberikan oleh guru. Adapun untuk hasil wawancara yang dilakukan kepada siswa yang memiliki nilai tertinggi, sedang, dan kurang dapat disimpulkan bahwa siswa senang dan tertarik mengikuti pembelajaran menulis puisi melalui teknik clustering dengan media foto jurnalistik. Siswa mulai merasa senang untuk menulis puisi yang sebelumnya tidak mereka suka dan siswa merasa semakin berminat menulis puisi.

\section{SIMPULAN DAN SARAN}

\section{Simpulan}

Berdasarkan hasil penelitian dan pembahasan, penulis menyimpulkan sebagai berikut: 1) Dari hasil siklus I, dan siklus II bahwa siswa sudah mengalami peningkatan di tiap aspek menulis puisi, ini terbukti dari perolehan rata-rata tiap aspek menulis puisi seperti aspek kesesuaian judul dengan isi pada siklus I nilai ratarata 76,7 adapun di siklus II mengalami peningkatan sebesar $6 \%$ menjadi 82,7 . Untuk aspek pilihan kata atau diksi mengalami peningkatan pada siklus I diperoleh nilai rata-rata 76,0 dan siklus II menjadi 80,5 dengan peningkatan sebesar 4,5\%. Aspek bahasa figuratif nilai rata-rata siswa pada siklus I 63,2 kemudian pada siklus II mengalami peningkatan sebesar 17,3\% dengan nilai ratarata 80,5. Untuk aspek versifikasi perolehan nilai rata-rata pada siklus I 60,2 dan pada siklus II menjadi 80,5 dengan peningkatan sebesar 20,3\%. Yang terakhir untuk aspek tipografi perolehan nilai rata-rata siklus I 72,7 dan pada siklus II menjadi 76,7 sehinggan memeroleh peningkatan sebesar 04\%; dan 2) Perilaku siswa kelas VIII.6 SMP Negeri 13 Pekanbaru dalam mengikuti pembelajaran menulis puisi melalui teknik clustering dengan media foto jurnalistik mengalami perubahan ke arah positif. Perubahan tersebut terlihat dari data nontes yaitu dari observasi, wawancara, catatan harian siswa, jurnal guru, dan dokumentasi foto. Hasil data nontes tersebut menunjukan siswa terlihat lebih antusias dan senang saat pembelajaran menulis puisi melalui teknik clustering dengan media foto jurnalistik.

\section{Saran}

Berdasarkan simpulan hasil penelitian tersebut, penulis memberi saran sebagai berikut: 1) Pembelajaran melalui teknik clustering dengan media foto jurnalistik hendaknya dapat dijadikan alternatif bagi guru untuk mengajarkan materi menulis puisi; dan 2) Para peneliti di bidang pendidikan atau peneliti lain hendaknya dapat melakukan penelitian yang serupa dengan teknik pembelajaran yang lain. Selain itu, penulis memberi saran, sebelum melakukan tindakan penelitian, peneliti hendaknya sudah mengenal dahulu siswa yang akan dijadikan sebagai responden penelitian sehingga siswa tidak merasa asing terhadap peneliti. 


\section{DAFTAR RUJUKAN}

Alfiah, dan Yunarko Budi Santosa. 2009. "Pengajaran Puisi: Sebuah Penelitian Tindakan Kelas”. Yogyakarta: Pustaka Pelajar.

Aminuddin.2004. "Pengantar Apresiasi Karya Sastra". Bandung: Sinar Algesindo.

Baribin, Raminah. 1990. "Teori dan Apresiasi Puisi”. Semarang: IKIP Semarang Press.

Brigley, Jude. "Owning up: Cahanging Attitude to School Work Through Poetry: Jude Brigley explores approaches to poetry which aim to develop students' individual voice and faster a sense of engagement with both homework and class work". English Drama Media 13 (2009):37+. Gale Arts, Humanities and Education Standard Package. Web. 1 May 2010.

DePorter, Bobbi, dan Mike hernacki. 2002. "Quantum Learning: Membiasakan elajar Nyaman dan Menyenangkan"diterjemahkan oleh Alwiyah Abdurrahman. Bandung: Kaifa.

DePorter, Bobbi, Mark DePorter, dan Sarah Singer-Nourie. 2008. "Quantum Teaching Mempraktikkan Quantum Learning di Ruang-ruang Kelas".Bandung: Kaifa.

Djojosuroto, Kinayati. 2006. "Pengajaran Puisi: Analisis dan Pemahaman". Bandung: Nuansa.

Jabrohim, Chairul Anwar, Suminto A. Sayuti. 2003. “Cara Menulis Kreatif”.Yogyakarta: Pustaka Pelajar Offset.

Keraf, Gorys. 2009. “Diksi dan Gaya Bahasa”. Jakarta: Gramedia Pustaka Utama.

Krisbiono, Agus Dias. 2010. "Peningkatan Keterampilan Menulis Puisi dengan Media Poster pada Siswa Kelas VII E SMP N 3 Larangan Brebes”.Jurusan Bahasa dan Sastra Indonesia. Fakultas Bahasa dan Seni. Universitas Negeri Semarang..

Magee,Wes. 2008. “Asyiknya Menulis Puisi”. Solo: Tiga Serangkai.

Mahardhika, Bagus Setya. 2007. "Peningkatan Kemampuan Menulis Puisi Bertema Patriotik dengan Media Lagu pada Siswa Kelas VIII di SMPN 1 Campurdarat". Skripsi. Program Studi Pendidikan Bahasa. Sastra Indonesia dan Daerah Jurusan Sastra Indonesia Fakultas Sastra Universitas Negeri Malang.

Nurudin. 2007. "Dasar-Dasar Penulisan”. Malang: UMM.

Rahardi, F. 2006. "Panduan Lengkap Menulis Artikel, Feature, dan Esai: Modul Dasar Pelatihan Jurnalistik bagi Pemula Dilengkapi dengan Aneka Contoh Tulisan”. Jakarta: Kawan Pustaka.

Sembodo, Edi. 2009. “Contekan Pintar Sastra Indonesia:untuk SMP dan SMA”. Jakarta: Hikmah.

Subyantoro. 2009. "Penelitian Tindakan Kelas". Semarang: CV. Widya Karya.

Sudjana, Nana, dan Ahmad Rivai. 2009. "Media Pengajaran:Penggunaan dan Pembuatannya" . Bandung:Sinar Baru Algesindo.

Suparno, dan Mohamad Yunus. 2006. "Keterampilan Dasar Menulis”. Jakarta: Universitas Terbuka.

Thobroni, M. 2008. “Obsesi: Jadi Penulis Beken!”. Jakarta: Mastara.

Waluyo, Herman J. 2003. "Apresiasi Puisi: Panduan untuk Pelajar dan Mahasiswa”. Jakarta: Gramedia Pustaka Utama. 